University of Nebraska - Lincoln

DigitalCommons@University of Nebraska - Lincoln

Nebraska Cooperative Fish \& Wildlife Research Nebraska Cooperative Fish \& Wildlife Research Unit -- Staff Publications

1994

\title{
Interactions between Larval White Crappie and Gizzard Shad: Quantifying Mechanisms in Small Ponds
}

\author{
Kevin L. Pope \\ South Dakota State University, kpope2@unl.edu \\ Dennis R. DeVries \\ Auburn University Main Campus
}

Follow this and additional works at: https://digitalcommons.unl.edu/ncfwrustaff

Part of the Other Environmental Sciences Commons

\footnotetext{
Pope, Kevin L. and DeVries, Dennis R., "Interactions between Larval White Crappie and Gizzard Shad: Quantifying Mechanisms in Small Ponds" (1994). Nebraska Cooperative Fish \& Wildlife Research Unit -Staff Publications. 62.

https://digitalcommons.unl.edu/ncfwrustaff/62
}

This Article is brought to you for free and open access by the Nebraska Cooperative Fish \& Wildlife Research Unit at DigitalCommons@University of Nebraska - Lincoln. It has been accepted for inclusion in Nebraska Cooperative Fish \& Wildlife Research Unit -- Staff Publications by an authorized administrator of DigitalCommons@University of Nebraska - Lincoln. 


\title{
Interactions between Larval White Crappie and Gizzard Shad: Quantifying Mechanisms in Small Ponds
}

\author{
Kevin L. Pope' and Dennis R. DeVries \\ Department of Fisheries and Allied Aquacultures, and Alabama Agricultural Experiment Station \\ Auburn University. Alabama 36849. USA
}

\begin{abstract}
To test potential competitive interactions between larvae of white crappie Pomoxis annularis and of gizzard shad Dorosoma cepedianum. we added adult gizzard shad to eight of twelve 0.1 -ha ponds that had been stocked with adult white crappies. Larval white crappies and larval gizzard shad appeared within 1 week of one another and larval white crappie density did not differ between treatments. Zooplankton density declined similarly between treatments, and zooplankton species composition and size did not differ. Although larval white crappie and larval gizzard shad had moderate diet overlap, prey selection by white crappie did not differ between treatments. During April, more than $70 \%$ of larval gizzard shad had empty stomachs, compared with less than $20 \%$ of larval white crappies. Age-0 gizzard shad recovery was extremely low $(<10$ $\mathrm{kg} / \mathrm{ha}$ ) in five of eight ponds. Daily ring counts from otoliths indicated that late-spawned gizzard shad had higher growth rates than early-spawned gizzard shad, whereas no such relationship existed for white crappie. At a given size, age-0 white crappies weighed more in ponds with gizzard shad than in ponds without them. Contrary to our predictions, gizzard shad did not negatively affect age- 0 white crappies.
\end{abstract}

The white crappie Pomoxis annularis is a valuable sport fish. In the USA, 11.7 million anglers spend an estimated 229.8 million days annually targeting crappies Pomoxis spp. (Hooe 1991). Numerous management techniques are used to enhance white crappie populations, including the imposition of size and bag limits (Colvin 1991), management of water levels (Mitzner 1981; Beam 1983), and control of excessive aquatic macrophytes (Maceina et al. 1991).

In small waters, most crappie management effort has been directed at reducing white crappie density, increasing prey density, or both (Gabelhouse 1984). Predation by a dense population of small (200-300 mm total length, TL) largemouth bass Micropterus salmoides can reduce crappie density in 0.7-11.1-ha impoundments (Gabelhouse 1984) and similar results have been obtained in larger impoundments up to 27 ha in Texas (Cichra et al. 1984) and up to 106 ha in Oklahoma (Boxrucker 1987).

Prey enhancement, including manipulation of populations of shad Dorosoma spp., although sound from a predator-prey perspective, has not always produced the desired results (DeVries and Stein 1990). Inconsistent results may be due to competition between age- 0 crappies and their prey.

\footnotetext{
I Present address: Department of Wildlife and Fisheries Sciences, South Dakota State University. Brookings, South Dakota 57007, USA.
}

Although large white crappies (larger than 160 or $170 \mathrm{~mm}$ TL) are piscivorous, small white crappies are particulate-feeding zooplanktivores (Siefert 1969; O'Brien et al. 1984). Similarly, age-0 (about 25-30 mm TL or smaller) gizzard shad $D$. cepedianum are particulate-feeding zooplanktivores (Kutkuhn 1958; Cramer and Marzolf 1970; Van Den Avyle and Wilson 1980), although larger gizzard shad are filter-feeding omnivores that feed on detritus, phytoplankton, zooplankton, and occasionally insects (Miller 1960; Bodola 1966; Baker and Schmitz 1971; Jester and Jensen 1972; Drenner et al. 1978). Thus, young gizzard shad and young white crappies may compete for food.

Both white crappie and gizzard shad spawn in the spring, the former when water temperatures are $14-23^{\circ} \mathrm{C}$ ( Tin $1982 \mathrm{a}$ ), and the latter at $10-24^{\circ} \mathrm{C}$ (Tin 1982b). Thus, the spawning times of white crappie and gizzard shad, relative to one another, may influence the outcome of interactions between their age-0 progeny. For example, if the water warms slowly, gizzard shad will spawn first and their larvae may gain an advantage over laterspawned white crappie larvae.

In $0.23-0.35$-ha ponds, total number and biomass of age- 0 white crappie decreased when either gizzard shad or threadfin shad $D$. petenense were present (Guest et al. 1990). Mechanisms suggested as explanations for this decline were (1) predation by shad on white crappie larvae and eggs, and (2) competition for food between white crappie and shad (Guest et al. 1990). Detection of predation 
by shad on eggs and larvae is difficult: in fact. Heidinger (1983) was unable to detect fish eggs in threadfin shad guts immediately after consumption.

As discussed above, diet overlap between age- 0 gizzard shad and white crappie may be important. Furthermore, Guest et al. (1990) found that the density of several zooplankton groups (Keratella spp., cyclopoid copepods, and Bosmina spp.) suppressed by white crappie were suppressed even further when threadfin shad were present. However, gizzard shad did not suppress any zooplankton taxon beyond the decrease caused by white crappie alone. Without data on larval fish abundance or diet, the mechanisms by which age-0 white crappie and shad interact remain undescribed. To examine the potential for competitive effects of age- 0 gizzard shad on age- 0 white crappies, we conducted a pond experiment consisting of two treatments - white crappies alone and white crappies with gizzard shad.

\section{Methods}

Pond preparation. - Twelve 0.1 -ha ponds at Auburn, Alabama, were drained and allowed to dry during December 1991-February 1992. Rotenone (Noxfish. $5 \%$ active ingredient; about $2 \mathrm{mg}$ L) was applied to remaining water on 4 February 1992. Empty ponds were treated with agricultural limestone $(544 \mathrm{~kg} / \mathrm{ha})$ to assure a total alkalinity of or higher than $20 \mathrm{mg} / \mathrm{L}$ during the experiment (Boyd 1982).

Ponds were filled to a depth of about $1 \mathrm{~m}$ on 18-26 February 1992 with water that was filtered through $0.2-\mathrm{mm}$-mesh screens. We fertilized the ponds with $10 \% \mathrm{~N}-34 \% \mathrm{P}_{2} \mathrm{O}_{5}-0 \% \mathrm{~K}_{2} \mathrm{O}$ liquid fertilizer at a rate of $9.5 \mathrm{~L} / \mathrm{ha}$ (Boyd 1981) upon filling and again on 9 April, 16 April, and 2 May, to obtain phytoplankton and zooplankton blooms similar to those observed in natural waters in the area.

Fish stocking. - We collected adult white crappies (mean \pm SE: $237 \pm 77 \mathrm{~mm}$ TL) from Jones Bluff Reservoir, Elmore County, Alabama, by using trap nets and electrofishing gear in NovemberDecember 1991. Additional white crappies were collected in March 1992, before fish spawned. We collected aduit gizzard shad (mean \pm SE: $157 \pm$ $29 \mathrm{~mm} \mathrm{TL}$ ) with electrofishing gear from Jones Bluff Reservoir and West Point Reservoir, Alabama-Georgia, in November 1991. Additional gizzard shad were collected in February 1992, before fish spawned.
Adult white crappies (160 fish/ha, 16 fish/pond. estimated $40 \mathrm{~kg} / \mathrm{ha}$ ) were stocked in all 12 ponds and gizzard shad ( $570 \mathrm{fish} / \mathrm{ha}, 57 \mathrm{fish} /$ pond, estimated $22 \mathrm{~kg} / \mathrm{ha}$ ) were stocked in eight randomly chosen ponds on 3-23 March 1992. Fish densities were in the range for southeastern U.S. lakes and reservoirs (Crandall et al. 1978; Grinstead et al. 1978: Timmons et al. 1979; Aggus et al. 1980).

During stocking, 16 randomly chosen white crappies and 57 gizzard shad were sacrificed, weighed (nearest gram), and measured (nearest millimeter $T L$ ) to estimate size and relative condition $\left(K_{n}\right.$; Swingle and Shell 1971) of stocked fish.

Larval fish and zooplankton collection. - We sampled larval fish weekly, 31 March-19 May 1992 with a 0.5 -m-diameter, $500-\mu \mathrm{m}$-mesh net. The net was pulled the entire length of the pond by two people (mean tow speed \pm SE: $1.0 \pm 0.01$ $\mathrm{m} / \mathrm{s})$. Two replicate tows separated by at least 1.5 $h$ were made in each pond. A flowmeter mounted in the mouth of the net allowed estimation of the volume of water filtered. Fish were preserved in ethanol and taken to the laboratory, where they were identified. counted, and subsampled $(N=25$ of each species per tow sample) for total length measurements (to the nearest millimeter).

Two replicate zooplankton samples were collected from each pond with a tube sampler (75 mm diameter; DeVries and Stein 1991) before larval fish samples were collected. Zooplankton samples were filtered through a $54-\mu \mathrm{m}-\mathrm{mesh}$ net and preserved in $4 \%$ sucrose-formalin solution (Haney and Hall 1973). In addition, Secchi depth was measured. and water temperature and dissolved oxygen were measured at the surface and at depths of 0.5 and $1 \mathrm{~m}$ after zooplankton samples were taken on 31 March-12 May.

On 25-26 May, when age-0 white crappies reached $30 \mathrm{~mm}$ TL in at least six ponds, the water depth was reduced to $0.75 \mathrm{~m}$ in all ponds and the fish population in each pond was sampled with a single haul of a $15.2 \times 2.4 \mathrm{~m}, 6.35-\mathrm{mm}$-mesh seine made throughout the length of the pond. We identified, counted, weighed (nearest $0.01 \mathrm{~g}$ ), and measured (nearest millimeter TL) fish from a subsample of all fish collected $(N=200$ of each species per pond), and measured the total biomass (nearest gram) of age- 0 and adult fish by species.

Laboratory analysis. -Zooplankton samples were adjusted to a known volume and at least 200 individuals from each of the most abundant taxa were counted from measured subsamples. Cladocerans were identified to genus, and copepods 
were identified as calanoid, cyclopoid. or nauplii. and counted under a dissecting microscope. The first 10 individuals of each taxon that were encountered were measured (nearest $0.01 \mathrm{~mm}$ ) with an ocular micrometer.

We removed stomachs from up to 10 larval white crappies from each pond, and from up to 10 larval gizzard shad from each pond that contained them. on each sample date to quantify diets. Prey items were removed under a dissecting microscope and measured (nearest $0.01 \mathrm{~mm}$ ). Prey length was converted to biomass with taxon-specific length-dry weight regressions for zooplankton (Dumont et al. 1975; Bottrell et al. 1976; Rosen 1981).

We quantified diet overlap between larval white crappie and larval gizzard shad with Schoener's overlap index (Schoener 1970), based on the average of the volume percentages (Wallace 1981). The formula for this index is

$$
S_{x y}=1-0.5\left(\sum_{i=1}^{n}\left|P_{x i}-P_{y i}\right|\right) \text {, }
$$

where $S_{x y}$ is the overlap between species $x$ and species $y, P_{x i}$ and $P_{y i}$ are the proportions of prey type $i$ in the diets of species $x$ and $y$, and $n$ is the number of food categories. The index ranges from 0 to 1; values near 0 indicate little overlap. and a value of 1 indicates complete overlap.

Prey selection by larval white crappie and larval gizzard shad was quantified with Chesson's alpha (Chesson 1978, 1983); the formula for this index is

$$
\text { alpha }=\frac{r_{i} / p_{i}}{\sum_{i}^{m}\left(r_{i} / p_{i}\right)}
$$

where alpha is the selection index for a prey taxon. $r_{i}$ is the proportion of prey type $i$ in the fish diet, $p_{i}$ is the proportion of prey type $i$ in the pond, and $m$ is the total number of prey types available. With this index, a value of $1 / m$ indicates neutral selection - that is, consumption of a prey type is in proportion to its abundance in the environment: values greater than this indicate positive selection and values less than this indicate negative selection.

Because daily growth rings have been validated, and relationships between fish length and otolith radius for age- 0 white crappie and gizzard shad have been demonstrated (Davis et al. 1985;
Sweatman and Kohler 1991), we used otoliths to assess daily growth rates. We removed sagittal otoliths from 10 age- 0 individuals of each species collected from each pond upon draining. Otoliths were dried and mounted convex side up on glass slides with thermoplastic cement. Mounted otoliths were ground with wet 600 -grit sandpaper. and polished on a polishing cloth with alumina powder, until the center rings were visible. A drop of low-viscosity (type-A) immersion oil was placed on the otolith to improve optical quality of the rings (Davis et al. 1985: Sweatman and Kohler 1991).

Independent daily ring counts by two readers were compared for precision; counts that differed by more than $3 \mathrm{~d}$ were reexamined by both readers until agreement was reached. Of the 120 white crappie otoliths, 2 were lost and 3 were not used because between-reader agreement could not be reached. Of the 41 gizzard shad otoliths, 2 were not used because agreement could not be reached. Three days were added to daily ring counts from gizzard shad otoliths, corresponding to time between hatch date and swim-up date (Davis et al. 1985); no days were added to white crappie daily ring counts because daily ring formation for white crappie begins at hatching (Sweatman and Kohler 1991). We back-calculated hatching date and average daily growth rate for both species from the daily ring counts. We also measured the otolith radius and distance from the otolith nucleus to the 10th, 20th, and 30th rings and back-calculated fish size at each age by the direct proportion method:

$$
\left(O_{a} / O_{r}\right) \cdot \mathrm{TL},
$$

where $O_{a}$ is the otolith distance to the ring at age $a$ and $O_{r}$ is the otolith radius.

We analyzed differences in larval white crappie density, zooplankton density and size, white crappie prey selection, percentage of larval white crappies with empty stomachs, temperature, dissolved oxygen, and Secchi depth between treatments with a split-plot repeated-measures analysis of variance (Maceina et al. 1994). Treatment effects were compared for the period of 31 March-19 May (i.e., from the first date of larval fish collection through 1 week before pond draining). Means were generated across samples within ponds and these means were used as replicate observations for analysis. We used covariate analysis to test for heterogeneity of slopes between treatments for age- 0 white crappie length-weight regressions. 

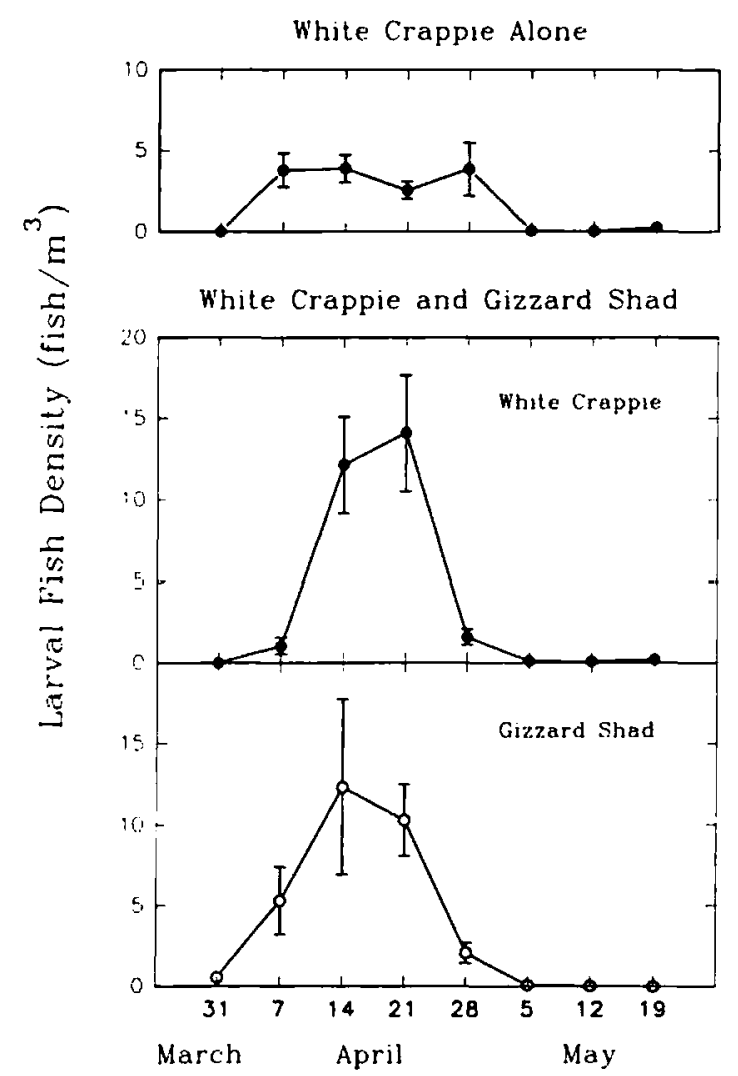

FIGURe 1.-Densities (mean \pm SE) of larval white crappies in ponds without gizzard shad (top panel), and of larval white crappies (middle panel) and larval gizzard shad (bottom panel) together in ponds.

\section{Results}

\section{Limnological Factors}

The limnological variables measured did not differ between treatments (surface temperature: $F$ $=2.32 ; \mathrm{df}=1,10: P=0.16 ;$ dissolved oxygen: $F$ $=0.67 ;$ df $=1,10 ; P=0.43 ;$ Secchi depth: $F=$ $2.75 ; \mathrm{df}=1,10 ; P=0.13)$. During the experiment, water temperature ranged from 14.0 to $26.0^{\circ} \mathrm{C}$ and dissolved oxygen remained above $5 \mathrm{mg} / \mathrm{L}$ at all depths.

\section{Larval Fish Density}

Larval white crappie density in ponds with gizzard shad peaked on 14-21 April, when larval gizzard shad density peaked (Figure 1). Larval white crappie density in ponds without gizzard shad peaked during 7-28 April (Figure 1). Although larval white crappie density did not differ between treatments $(F=2.75$; df $=1,10 ; P=$ 0.13 ). the treatment $\times$ date interaction was sig- nificant $(F=3.47 ; \mathrm{df}=8,79 ; P=0.002)$. Larval white crappies in the presence of gizzard shad had a more distinct peak abundance than larval white crappies without gizzard shad.

\section{Zooplankton}

Zooplankton density was highest on 31 March in both treatments and declined steadily thereafter (Figure 2). Zooplankton density did not differ between treatments $(F=1.39$; df $=1,10 ; P=0.27)$ and the treatment $x$ date interaction was not significant $(F=1.39$; df $=8,80 ; P=0.21)$. Zooplankton taxonomic composition was qualitatively similar between treatments (Figure 2) and mean zooplankton size did not differ between treatments $(F=0.48$; $\mathrm{df}=1,10 ; P=0.50$; Figure 2$)$. The only taxon that showed a difference between treatments was Ceriodaphnia: these zooplankters differed in mean size between treatments $(F=4.74$; $\mathrm{d} f=1,10 ; P=0.05 ;$ Figure 3 ), and the treatment $x$ date interaction for this variable was also significant $(F=2.25 ; \mathrm{df}=7,10 ; P=0.05$; Figure 3$)$.

\section{Larval Fish Diets}

The mean percentage of larval white crappies with empty stomachs differed marginally between treatments (treatment effect: $F=3.94$; dr $=1,10$; $P=0.075$; treatment $\times$ date interaction: $F=0.83$; $\mathrm{df}=3,18 ; P=0.49$; Figure 4). Across dates, the mean percentage of larval white crappies with empty stomachs was $18 \%$ in ponds without gizzard shad and $7 \%$ in ponds with gizzard shad. Across dates, the mean percentage of larval gizzard shad with empty stomachs was $76 \%$.

Crustacean zooplankton dominated the diets of larval white crappies and gizzard shad in terms of both biomass and number. Rotifers accounted for $8 \%$ of prey biomass of larval gizzard shad and $2.5 \%$ of prey biomass of larval white crappies. In addition, rotifers accounted for $8 \%$ of the number of prey items of larval gizzard shad and less than $3 \%$ of the number of prey items of larval white crappies. Because rotifers contributed little to the diet of larval fish in this experiment, we did not consider rotifers in further analyses.

With gizzard shad present, small $(<10 \mathrm{~mm}$ TL) white crappies positively selected copepod nauplii, whereas larger ( $\geq 10 \mathrm{~mm} T L$ ) white crappies exhibited negative selection for them (Figure 5). In addition, small white crappies in ponds with gizzard shad positively selected Diaphanosoma. All white crappies in both treatments showed negative selection for cyclopoid copepods. Across time, larval white crappie prey selection did not 
White Crappie

Alone

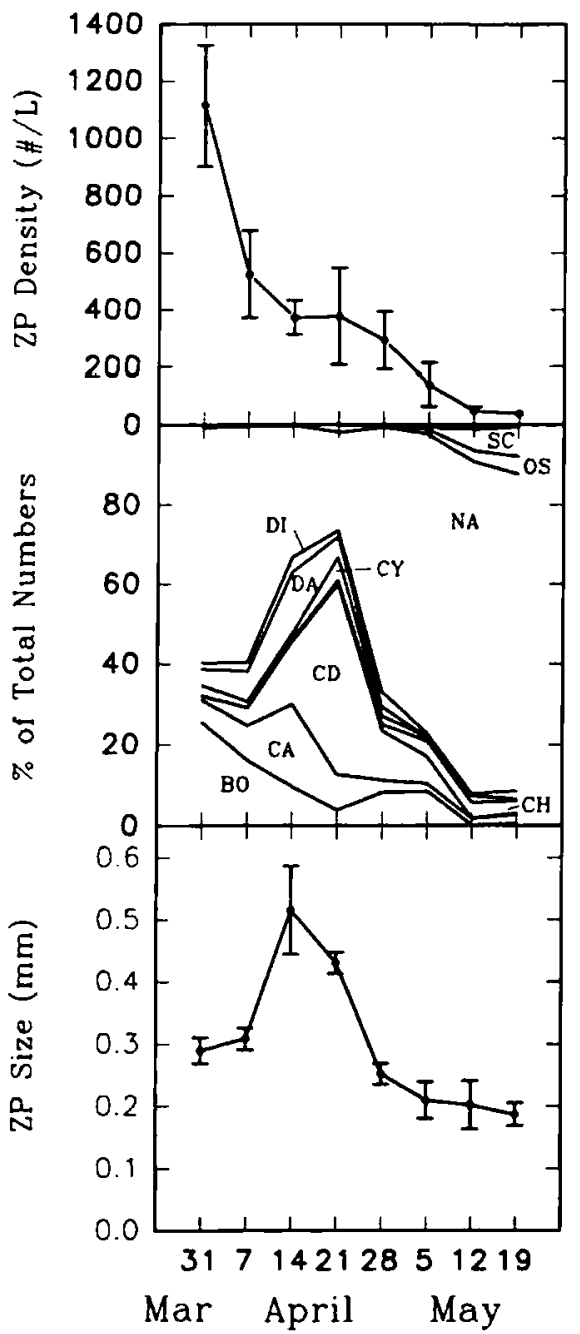

White Crappie and

Gizzard Shad

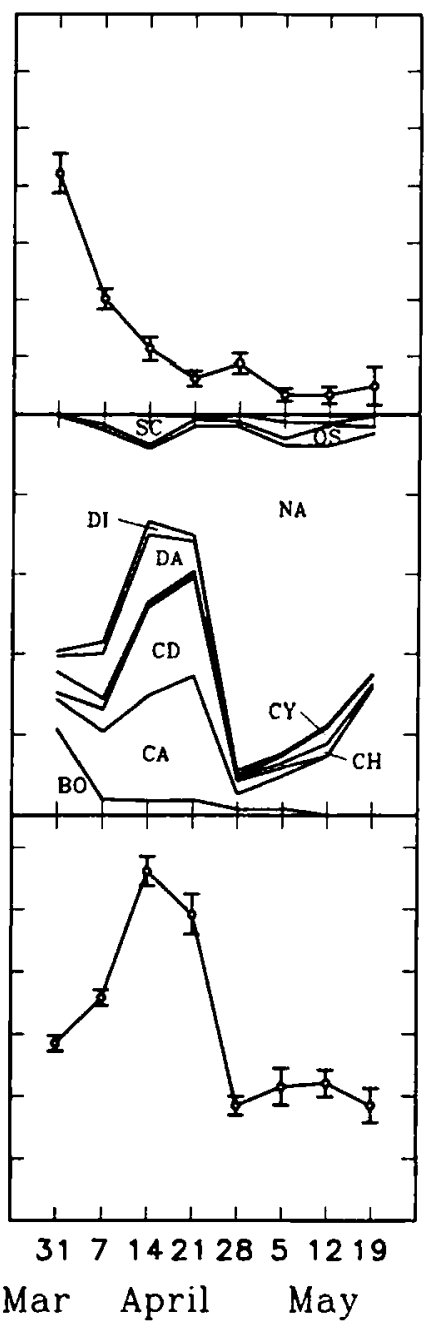

FIGURE 2.-Densities (mean $\pm S E$, number/L; top panels), percent composition by number (middle panels), and sizes (mean $\pm \mathrm{SE}, \mathrm{mm}$; bottom panels) of crustacean zooplankton (ZP) from ponds with white crappies only (left panels) and from ponds with white crappies plus gizzard shad (right panels). Zooplankton taxa are indicated as follows: $\mathrm{BO}=$ Bosmina, $\mathrm{CA}=$ calanoid copepods, $\mathrm{CD}=$ Ceriodaphnia, $\mathrm{CH}=$ Chydorus, $\mathrm{CY}=$ cyclopoid copepods, DA = Daphnia, DI $=$ Diaphanosoma, NA $=$ copepod nauplii, $\mathrm{SC}=$ Scapholeberis, and $\mathrm{OS}=$ ostracods.

differ between treatments (all $P>0.36$ ). Although gizzard shad exhibited negative selection of larger zooplankton such as Ceriodaphnia. Chydorus, Daphnia, and cyclopoid copepods, they did not positively select any prey groups (Figure 5 ).

Mean diet overlap (Schoener's overlap index) between larval white crappies and gizzard shad when combined was 0.17 on 7 April, 0.58 on 14 April, 0.37 on 21 April, and 0.11 on 28 April. Overlap on 14 April was entirely due to both spe- cies consuming copepod nauplii and Diaphanosoma. Overlap on 21 April was due primarily to the components of Bosmina. Ceriodaphnia. Diaphanosoma, and ostracods in the diet, although calanoid copepods and copepod nauplii also contributed.

\section{Recovery of Age-O Fish}

Adult fish spawned successfully in all ponds. as evidenced by the presence of larvae. However, no 

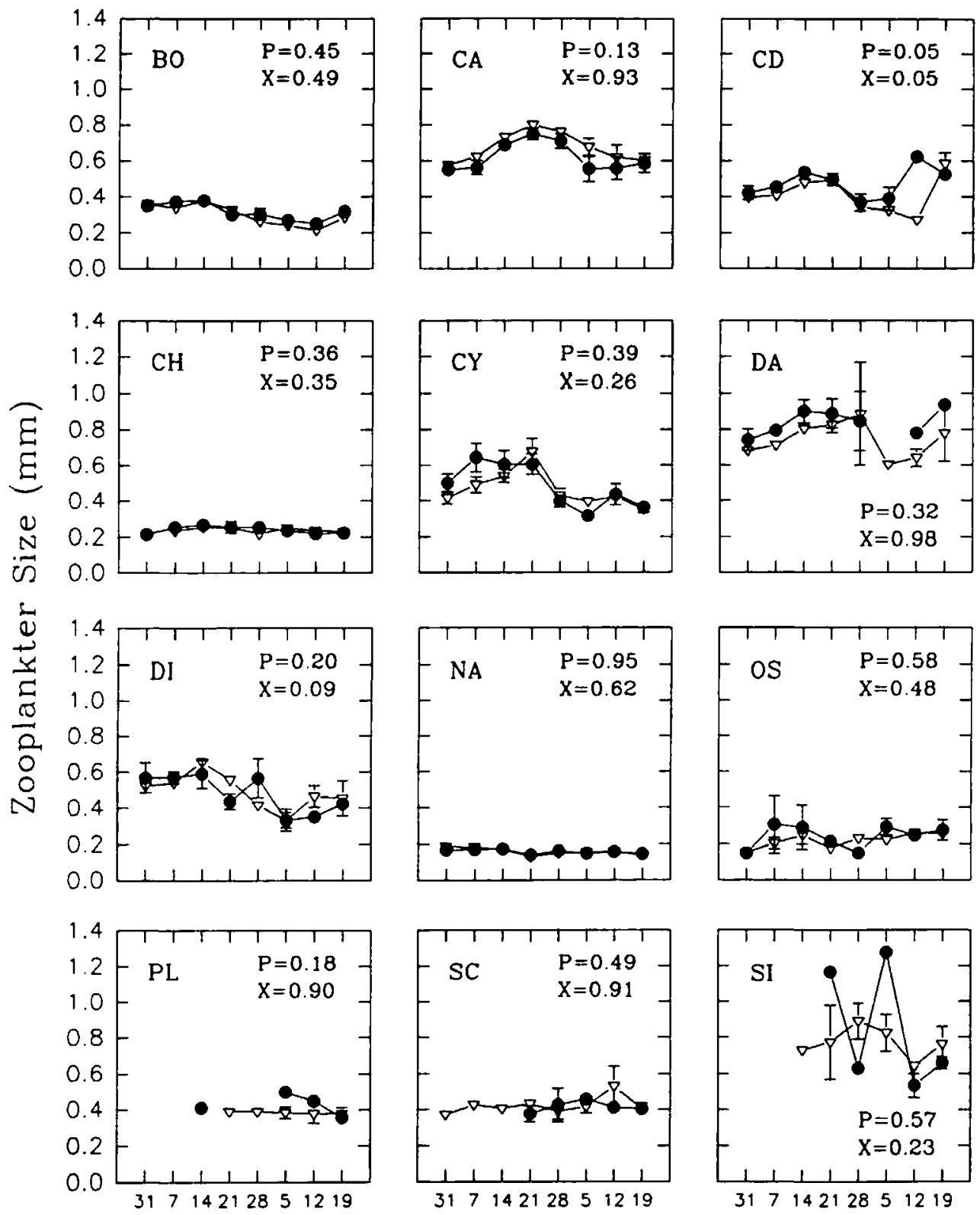

\section{Mar April May}

Mar April May

Mar April May

FIGURE 3.-Sizes (mean $\pm S E$ ) of crustacean zooplankton, by taxon, from ponds with white crappies only (circles) and from ponds with white crappies plus gizzard shad (triangles). Abbreviations for zooplankton taxa are those defined in Figure 2, plus $\mathrm{PL}=$ Pleuroxus and $\mathrm{SI}=$ Simocephalus. The $\boldsymbol{P}$-values are probability values for a test of treatment differences, and $X$-values are probability values of treatment $\times$ date interaction from a split-plot, repeatedmeasures ANOVA.

age-0 gizzard shad were recovered from three gizzard shad ponds when the ponds were drained. Of the remaining five ponds with gizzard shad, the biomass of recovered age- 0 gizzard shad was extremely low in two ( 1 and $10 \mathrm{~kg} / \mathrm{ha})$, moderate in two $(1,640$ and $3,640 \mathrm{~kg} / \mathrm{ha})$, and high in one $(11,680 \mathrm{~kg} / \mathrm{ha})$. Biomass of recovered age -0 white crappies was $150-31,150 \mathrm{~kg} / \mathrm{ha}$ and was not different between treatments $(t=1.41 ; \mathrm{df}=3 ; P=$ 0.25 ). The biomass of recovered age- 0 gizzard shad 
was not related to that of recovered age- 0 white crappies $(P=0.23)$ or to that of adult white crappies $(P=0.45)$.

\section{Hatch Date and Growth of Age-O Fish}

Age-0 white crappies that were recovered at the end of the experiment had hatched on 3-25 April and the age-0 gizzard shad had hatched on 6-20 April (timing similar to that shown by larval abundance patterns in Figure 1). Daily growth of weekly cohorts of white crappies (white crappies hatched on 8-14 April constitute one weekly cohort) did not differ across cohort hatch dates (with gizzard shad: $F=0.28$; df $=3,75 ; P=0.84$; without gizzard shad: $F=0.13$; $\mathrm{df}=3,32 ; P=$ $0.94)$, whereas daily growth of gizzard shad weekly cohorts did differ $(F=8.83 ; \mathrm{df}=2,36 ; P=0.0008)$. For gizzard shad, the relationship between overall average daily growth and hatch date was positive $(r=0.66, P=0.0001$; Figure 6$)$, as was the case with each of the 10-d growth rates (days 1-10: $r$ $=0.39, P=0.01$; days 11-20: $r=0.48, P=0.002$; days 21-30: $r=0.71, P=0.0001$; Figure 6). In addition, daily growth (TL) of white crappie with gizzard shad (mean $\pm \mathrm{SE}=0.65 \pm 0.15 \mathrm{~mm}$ ) did not differ from that of white crappie without gizzard shad (mean $\pm \mathrm{SE}: 0.69 \pm 0.17 \mathrm{~mm} ; F=$ $0.19 ;$ df $=1,111 ; P=0.67$ ).

\section{Length-Weight Regression for Age-O Fish}

The slope of the regression of weight on length for age-0 white crappies $(10-50 \mathrm{~mm}$ TL) recovered at the end of the experiment (25-26 May) was greater in treatments with gizzard shad than in those without (ANCOVA; $F=8.76 ; \mathrm{df}=1$ and 2,272; $P=0.003$ ). The length-weight regression formulas (with weight in grams and TL in millimeters) were as follows:

for white crappies in ponds without gizzard shad $\left(r^{2}=0.86\right)$,

$$
\log _{10} \text { weight }=3.245\left(\log _{10} \mathrm{TL}\right)-5.521
$$

for white crappies in ponds with gizzard shad $\left(r^{2}\right.$ $=0.88$ ),

$$
\log _{10} \text { weight }=3.409\left(\log _{10} \mathrm{TL}\right)-5.668
$$

and for gizzard shad $\left(r^{2}=0.92\right)$,

$$
\log _{10} \text { weight }=3.505\left(\log _{10} \mathrm{TL}\right)-5.816 \text {. }
$$

\section{Discussion}

Based on previous work with early life stages of gizzard shad and white crappie, we generated ex-

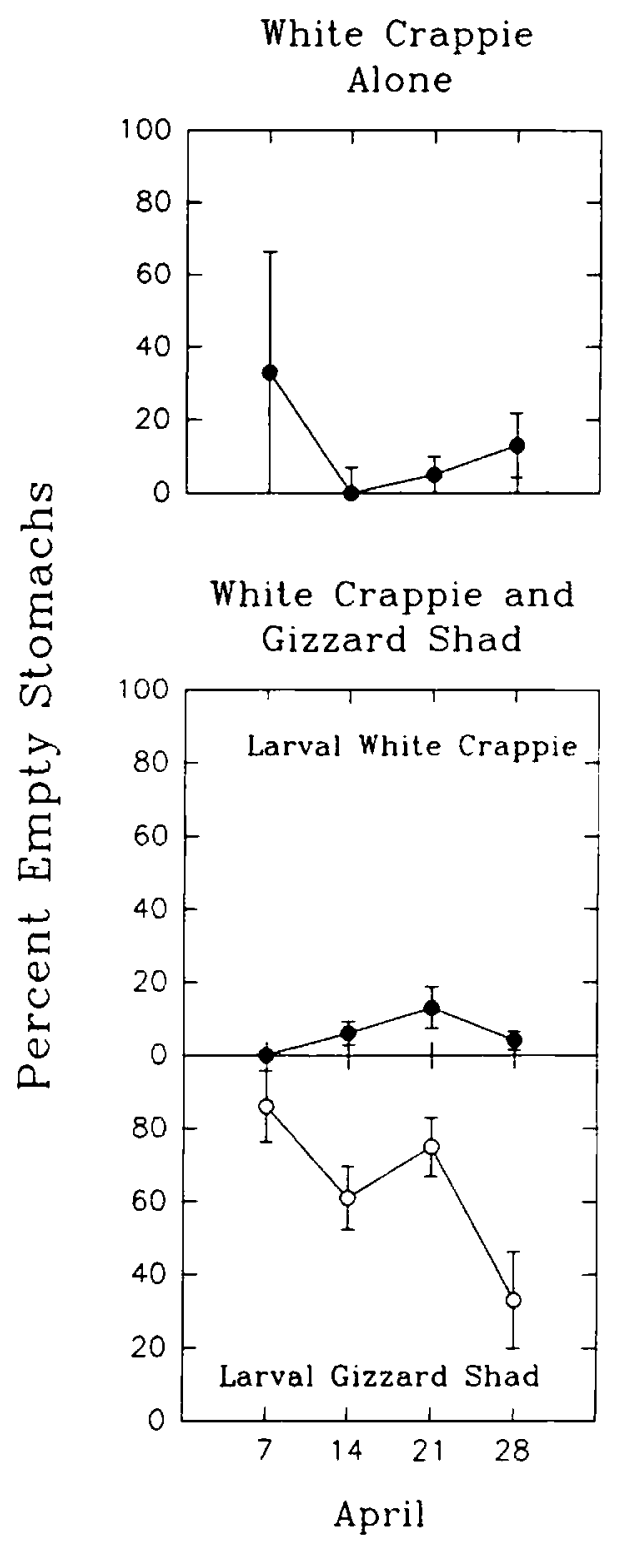

Figure 4. - Percentages (mean \pm SE) of fish with empty stomachs in ponds where larval white crappies were kept without gizzard shad (top panel), and in ponds where larval white crappies (middle panel) and larval gizzard shad (bottom panel) were kept together.

plicit predictions for interactions between them in small ponds. Although gizzard shad can reduce zooplankton abundance directly by predation, and may also do so indirectly by nutrient limitation (DeVries and Stein 1992), gizzard shad in the presence of white crappie may not reduce zooplankton abundance below the level caused by 
White Crappie Alone
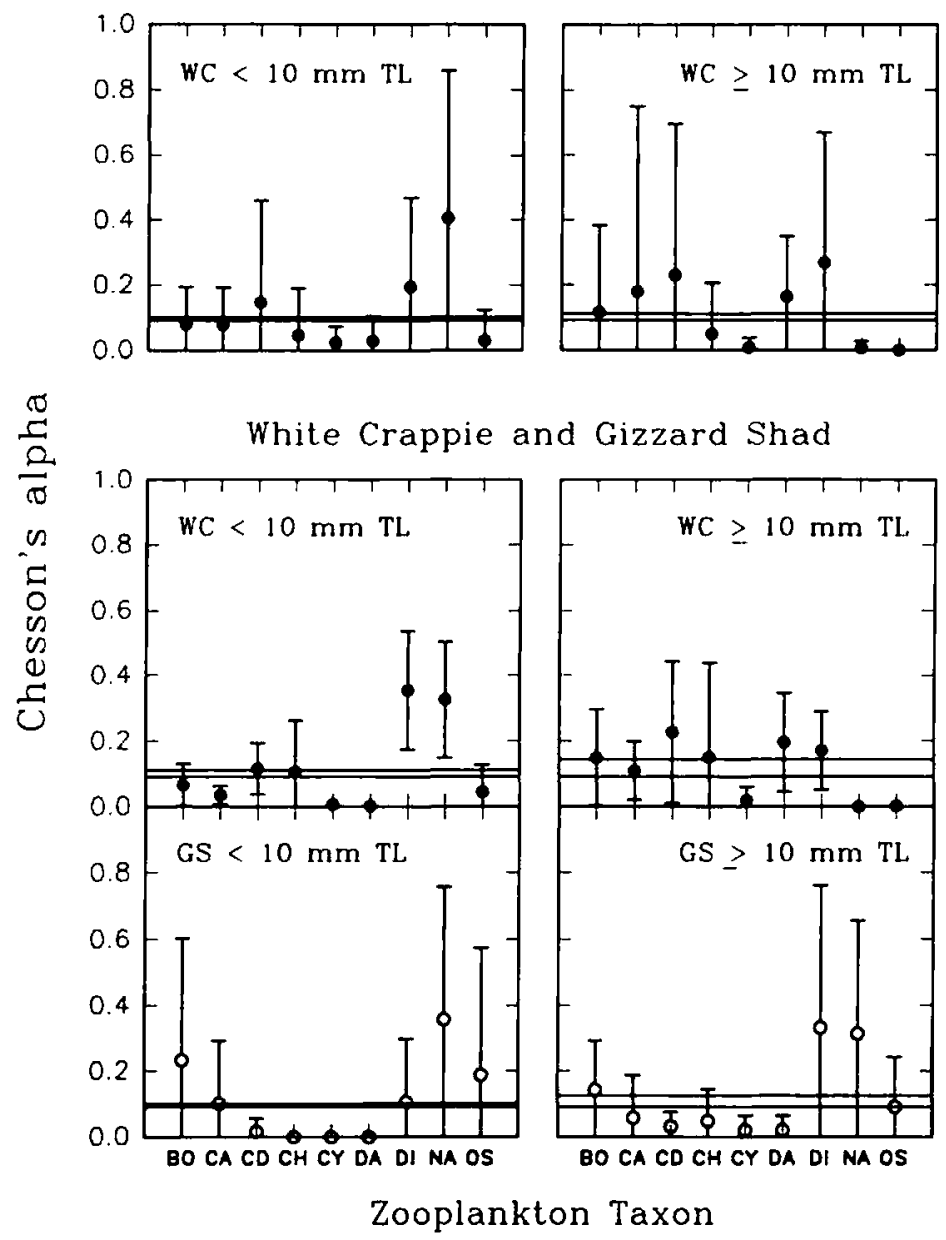

(Small $\rightarrow$ Large)

FIGURE 5.-Prey selection (Chesson's alpha; mean $\pm 95 \%$ confidence intervals) by larval white crappies (WC) in ponds without gizzard shad (top panels), and by larval white crappies (middle panels) and larval gizzard shad (GS: bottom panels) together in ponds. Larvae were grouped by total length (TL; left panels: small fish; right panels: larger fish). Prey taxa are ordered in increasing mean size from left to right. Abbreviations for taxa are as in Figure 2. Horizontal lines represent the range of neutral selection, determined as the reciprocal of the number of available prey groups; values above this range indicate positive selection and values below this range indicate negative selection.

white crappie alone (Guest et al. 1990). Thus, we did not expect zooplankton abundance to be suppressed more in white crappie ponds with gizzard shad than in those without gizzard shad. As predicted, zooplankton abundance in ponds with gizzard shad and white crappie did not differ from that in ponds with white crappie alone.

We expected that diets of larval white crappie and gizzard shad would overlap, because both species are particulate-feeding zooplanktivores (Kut- kuhn 1958; Siefert 1969; Cramer and Marzolf 1970; Van Den Avyle and Wilson 1980; O'Brien et al. 1984). As predicted, diets of larval white crappies and larval gizzard shad overlapped. However, we expected that the diet overlap between larvae of these two species would lead to reduced survival of age- 0 white crappies, and subsequent increased growth due to reduced intraspecific competition (as reported in Guest et al. 1990). Our findings were to the contrary: gizzard 


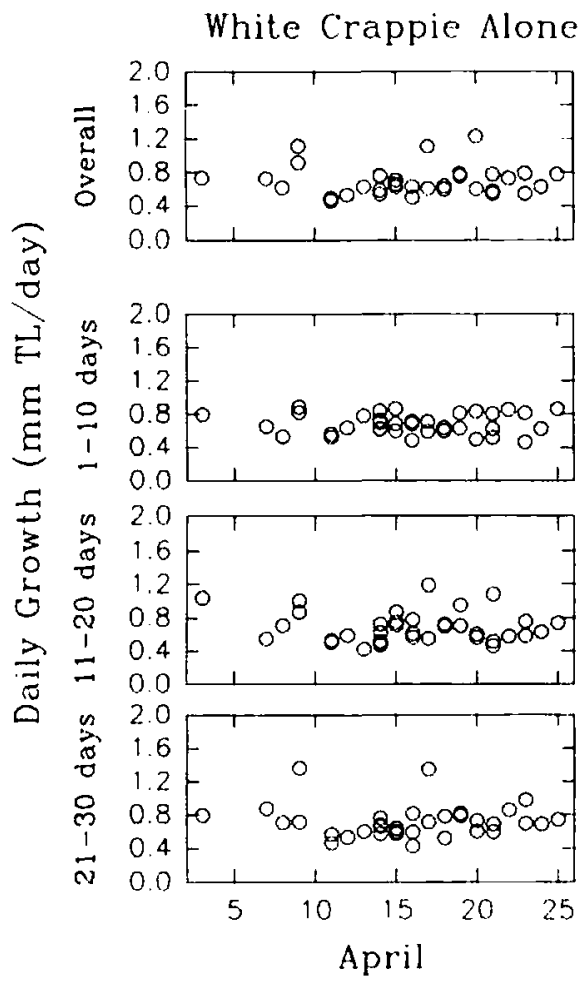

White Crappie with

Gizzard Shad
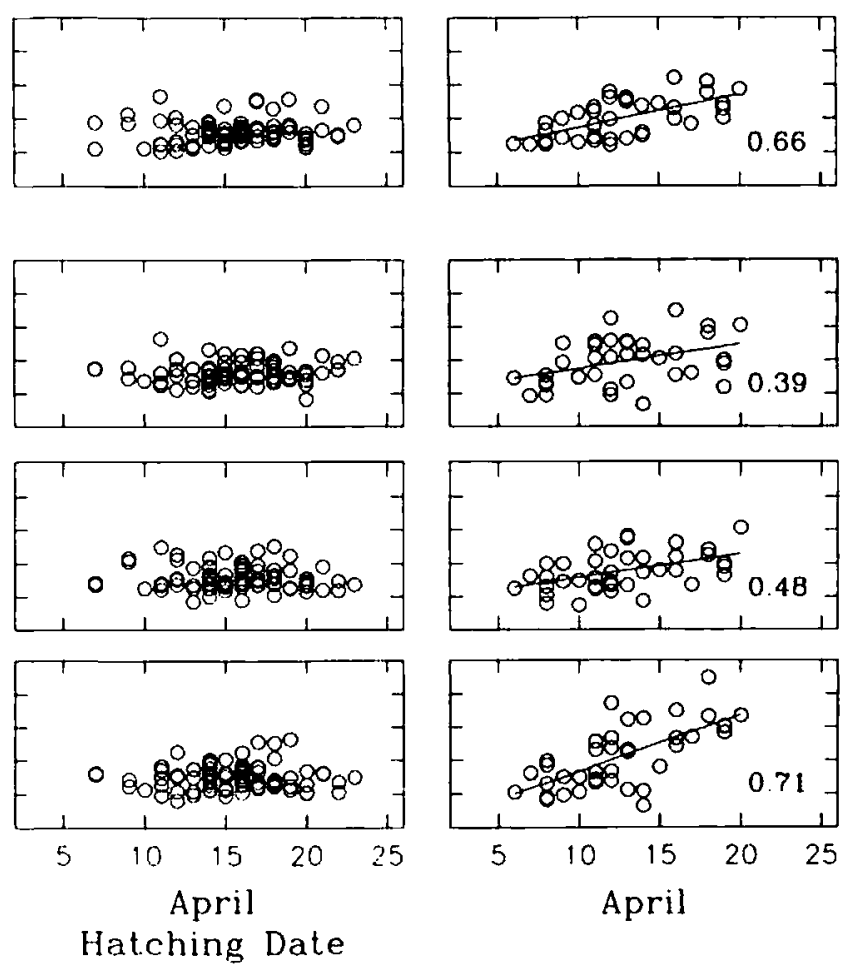

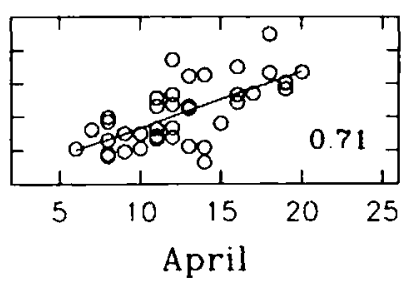

FIGURE 6. - Growth ( $\mathrm{mm}$ total length/d) as a function of hatch date for age-0 white crappies in ponds without gizzard shad (left panels), and for white crappies (middle panels) and gizzard shad (right panels) together in ponds. The top row of panels presents overall average daily growth (size/age), and the second through fourth rows show average daily growth for three consecutive 10-d periods (days 1-30). Age was determined from daily ring counts from otoliths, and back-calculation of size was made by the direct proportion method. Lines are present for significant regressions (all $P<0.02$ ) and numbers represent $r$-values. None of the regressions for white crappies were significant (all $P>0.35$ ).

shad did not affect abundance or daily growth of age- 0 white crappies. In fact, at a given size, age- 0 white crappies recovered from ponds with gizzard shad weighed more than their counterparts from ponds without gizzard shad. This difference was likely related to the lower percentage of larval white crappies with empty stomachs in ponds with gizzard shad than in ponds without them.

We suggest that the adult gizzard shad, through their feeding activity, may have indirectly contributed to the success of age- 0 white crappies. Age- 1 and older gizzard shad typically feed on detritus and bottom sediment (Baker and Schmitz 1971; Pierce et al. 1981). Sedimentation often removes a substantial portion of nutrients from the water (Boyd and Musig 1981). Sediment feeding by adult gizzard shad feeding may resuspend sediments and increase phosphorus concentrations in the water column (Brabrand et al. 1990). Additionally, Havens (1993) found that total phosphorus and chlorophyll concentrations where higher in enclosures where fish had access to the sediments than in enclosures with nets blocking access to the sediments. If similar nutrient increases occurred in our ponds, phytoplankton production could have increased in gizzard shad ponds relative to that in white crappie ponds, leading to additional zooplankton production for consumption by larval fish. Alternatively, age- 0 white crappies in the two-species ponds could have preyed on age- 0 gizzard shad during May. However, such predation was unlikely because the age- 0 length distributions of both species were similar, which would make it difficult for age- 0 white crappies to prey on age-0 gizzard shad.

Our a priori predictions were based on the ex- 
pectation that larval gizzard shad would appear before larval white crappies and substantially influence zooplankton dynamics. Although larval gizzard shad appeared first, peak larval abundance of both species occurred at similar times, and peak larval white crappie abundance was similar between treatments. We suggest that our results did not agree with many of our a priori predictions because neither species gained an exploitative advantage relative to consumption of zooplankton. For example, larval bluegills Lepomis macrochirus typically appear several weeks after larval gizzard shad and, given that juvenile gizzard shad can reduce zooplankton density (DeVries and Stein 1992: Dettmers and Stein 1992), feeding. survival, and recruitment of age- 0 bluegills can be reduced in the presence of gizzard shad (DeVries et al. 1991).

Our results clearly differed from those of Guest et al. (1990), who found that threadfin and gizzard shad both reduced total number and biomass of age- 0 white crappies. We suggest that the relative spawning times of gizzard shad and white crappies caused the outcome of between-larva interactions in our experiment to differ from that in Guest et al. (1990). The factor likely responsible for variation in relative spawning times of white crappie and gizzard shad was the rate of increase of water temperature from 10 to $14^{\circ} \mathrm{C}$. the lower end of spawning temperature for gizzard shad and white crappie, respectively ( $\operatorname{Tin} 1982 \mathrm{a}, 1982 \mathrm{~b}$ ). For example, if a water temperature increase from 10 to $14^{\circ} \mathrm{C}$ requires 1 week, then larval gizzard shad could be present 1 week before white crappies; however, if this warming takes only $1-2 \mathrm{~d}$. gizzard shad would have no advantage. Alternatively, differences in relative spawning times may have been caused by differences in adult fish sizes. Within a species, large fish may spawn before small fish (Whiteside 1962; Willis 1987; Miranda and Muncy 1988). Therefore, the relative spawning times (and subsequent interactions among larvae) in a system containing large adult gizzard shad and small adult white crappies will likely be different than in a system containing small adult gizzard shad and large adult white crappies.

\section{Implications for Closely Related Species}

Although gizzard shad and threadfin shad are similar in a number of characteristics. there are some important differences between them. Adult gizzard shad feed primarily on organic detritus, phytoplankton, filamentous algae, and zooplankton, whereas threadin shad feed limnetically on zooplankton, phytoplankton, and periphyton (Baker and Schmitz 1971). Also, larval threadfin shad have a more pronounced offshore migration than larval gizzard shad (Allen and DeVries 1993). However, diets of larvae of the two species are similar (Kutkuhn 1958; Cramer and Marzolf 1970; Holanov and Tash 1978; Van Den Avyle and Wilson 1980), and Guest et al. (1990) found that white crappies were negatively affected by both shad species. Therefore, the outcome of larval competition for zooplankton between white crappies and threadfin shad is likely similar to that between white crappies and gizzard shad, and relative spawning times of threadfin shad and white crappies may be important. Because larval threadfin shad appear after gizzard shad (Allen and DeVries 1993: Hirst and DeVries 1994), we expect that threadfin shad would be less likely than gizzard shad to have a negative effect on white crappie. However. the presence of adult shad could lead to different predictions if benthic feeding by adult gizzard shad resuspends nutrients in the water and serves to enhance age- 0 white crappie condition. Although threadfin shad can feed on benthic organisms. they typically feed on limnetic resources and only switch to benthos when zooplankton becomes limiting (Ingram and Ziebell 1983). Therefore, it is unlikely that adult threadfin shad would enhance condition of age- 0 white crappie, as may have occurred with gizzard shad.

Similarly, larval black crappie $P$. nigromaculatus and white crappie exhibit differences. Chatry and Conner (1980) consistently collected larval black crappies earlier than white crappies and therefore suggested that black crappie spawns before white crappie. In addition, Overmann et al. (1980) observed that juvenile white crappies fed primarily on the bottom, whereas juvenile black crappies fed at the surface. Nevertheless, prey selection did not differ between species (Overmann et al. 1980). Therefore, the potential exists for black crappie to interact with gizzard or threadfin shad in the same way as white crappie. However, if black crappie spawns earlier than white crappie. gizzard shad may have fewer or less severe negative effects on black crappie than it has on white crappie.

\section{Conclusions}

Gizzard shad have historically been an important management tool. introduced to enhance the available prey for piscivorous sport fishes (DeVries and Stein 1990). Concerns have been raised about the potential negative effects of gizzard shad 
on members of the fish community. In particular, introduced gizzard shad can compete with resident sport fish like white crappie for zooplankton, and the subsequent negative effects could offset any positive effects of increased prey availability to adult piscivores. Hence, our prediction, based on previous work with white crappie and gizzard shad, was that gizzard shad would negatively influence age- 0 white crappie. Clearly this was incorrect. Although larval white crappies and gizzard shad appeared within 1 week of one another, neither larval white crappie density nor recovered age- 0 white crappie biomass differed between ponds with and those without gizzard shad. Our results indicate that the effects of gizzard shad should not be assumed to be negative in all situations, despite the possibility that age- 0 gizzard shad may compete with planktivorous age- 0 sport fish.

\section{Acknowledgments}

We appreciate the advice we received from $J$. Dettmers and $R$. Drenner as we designed this experiment. We thank M. Allen, D. Armstrong, W. Black. T. DeVries, S. Hirst. K. Pope, N. Pope, S. Pope. J. Putman, B. Shaner, F. Snow, and V. Travnicek for help in the field and laboratory. We also thank W. Davies, J. Dettmers, M. Golden, M. Maceina, R. Phelps, and D. Willis for helpful comments on an earlier draft of this manuscript. This work was supported in part by funds from the National Science Foundation. grant DEB9108986, and Federal Aid in Sport Fish Restoration, project $F-40-R$, administered by the Alabama Department of Conservation and Natural Resources, to D.R.D. This is journal paper 8-933610 of the Alabama Agricultural Experiment Station.

\section{References}

Aggus, L. R., D. C. Carver, L. L. Olmsted. L. L. Rider, and G. L. Summers. 1980. Evaluation of standing crops of fishes in Crooked Creek Bay. Barkley Lake. Kentucky. Proceedings of the Annual Conference Southeastern Association of Fish and Wildlife Agencies 33(1979):710-722.

Allen. M. S., and D. R. DeVries. 1993. Spatial and temporal heterogeneity of larval shad in a large impoundment. Transactions of the American Fisheries Society 122:1070-1079.

Baker, C. D.. and E. H. Schmitz. 1971. Food habits of adult gizzard and threadfin shad in two Ozark Reservoirs. American Fisheries Society Special Publication 8:3-11.

Beam, J. H. 1983. The effect of annual water level management on population trends of white crappie in Elk City Reservoir. Kansas. North American Journal of Fisheries Management 3:34-40.

Bodola, A. 1966. Life history of the gizzard shad, Dorosoma cepedianum (LeSueur), in western Lake Erie. U.S. Fish and Wildlife Service Fishery Bulletin 65: $391-425$

Bottrell, H. H., and eight coauthors. 1976. A review of some problems in zooplankton production studies. Norwegian Journal of Zoology 24:419-456.

Boxrucker, J. 1987. Largemouth bass influence on size structure of crappie populations in small Oklahoma impoundments. North American Journal of Fisheries Management 7:273-278.

Boyd. C. E. 1981 . Ferilization of warmwater fish ponds. Journal of Soil and Water Conservation 36:142145.

Boyd, C. E. 1982. Liming fish ponds. Journal of Soil and Water Conservation 37:86-88.

Boyd, C. E.. and Y. Musig. 1981. Orthophosphate uptake by phytoplankton and sediment. Aquaculture 22:165-173.

Brabrand, A., B. A. Faafeng, and J. P. M. Nilssen. 1990. Relative importance of phosphorus supply to phytoplankton production: fish excretion versus external loading. Canadian Journal of Fisheries and Aquatic Sciences 47:364-372.

Chatry. M. F., and J. V. Conner. 1980. Comparative developmental morphology of the crappies. Pomoxis annularis and $P$. nigromaculatus. Pages 4557 in L. A. Fuiman, editor. Proceedings of the fourh annual larval fish conference. University of Michigan, Ann Arbor.

Chesson, J. 1978. Measuring preference in selective predation. Ecology 59:211-215.

Chesson. J. 1983. The estimation and analysis of preference and its relationship to foraging models. Ecology 64:1297-1304.

Cichra, C. E., R. L. Noble, and B. W. Farquhar. 1984. Relationships of white crappie populations to largemouth bass and bluegill. Proceedings of the Annual Conference Southeastem Association of Fish and Wildlife Agencies 35(1981):416-423.

Colvin. M. A. 1991. Population characteristics and angler harvest of white crappies in four large Missouri reservoirs. North American Journal of Fisheries Management 11:572-584.

Cramer, J. D., and R. Marzolf. 1970. Selective predation on zooplankton by gizzard shad. Transactions of the American Fisheries Society 99:320-332.

Crandall, P. S. B. W. Lyons, and R. W. Luebke. 1978. Evaluation of gill net and rotenone sampling with total reservoir drawdown. Proceedings of the Annual Conference Southeastern Association of Fish and Wildlife Agencies 30(1976):222-229.

Davis, R. D., T. W. Storck, and S. J. Miller. 1985. Daily growth increments in the otoliths of youngof-the-year gizzard shad. Transactions of the American Fisheries Society 114:304-306.

Dettmers, J. M., and R. A. Stein. 1992. Food consumption by larval gizzard shad: zooplankton effects and its implications for reservoir communi- 
ties. Transactions of the American Fisheries Society 121:494-507.

DeVries, D. R., and R. A. Stein. 1990. Manipulating shad to enhance spon fisheries in North America: an assessment. North American Journal of Fisheries Management 10:209-223.

DeVries. D. R.. and R. A. Stein. 1991. Comparison of three zooplankton samplers: a taxon-specific assessment. Journal of Plankton Research 13:53-59.

DeVries. D. R., and R. A. Stein. 1992. Complex interactions between fish and zooplankton: quantifying the role of an open-water planktivore. Canadian Journal of Fisheries and Aquatic Sciences 49:12161227

DeVries. D. R.. R. A. Stein, J. G. Miner, and G. G. Mittelbach. 1991. Stocking threadfin shad: consequences for young-of-year fishes. Transactions of the American Fisheries Society 120:368-381.

Drenner, R. W.. J. R. Strickler, and J. W. O'Brien. 1978. Capture probability: the role of zooplankter escape in the selective feeding of planktivorous fish. Journal of the Fisheries Research Board of Canada 35: 1370-1373.

Dumont. H. J.. I. Van de Velde, and S. Dumont. 1975. The dry weight estimate of biomass in a selection of Cladocera. Copepoda and Rotifera from the plankton, periphyton and benthos of continental waters. Oecologia (Berlin) 19:75-97.

Gabelhouse, D. W..Jr. 1984. An assessment of crappie stocks in small midwestern private impoundments. North American Journal of Fisheries Management 4:371-384.

Grinstead, B. G., R. M. Gennings. G. R. Hooper. C. A. Schultz, and D. A. Whorton. 1978. Estimation of standing crop of fishes in the predator-stockingevaluation reservoirs. Proceedings of the Annual Conference Southeastem Association of Fish and Wildlife Agencies 30(1976): 120-130.

Guest, W. C.. R. W. Drenner, S. T. Threlkeld, F. D. Martin. and J. D. Smith. 1990. Effects of gizzard shad and threadfin shad on zooplankton and young. of-year white crappie production. Transactions of the American Fisheries Society 119:529-536.

Haney, J. F.. and D. J. Hall. 1973. Sugar-coated daphnia: a preservation technique for cladocera. Limnology and Oceanography 18:331-333.

Havens. K. E. 1993. Responses to experimental fish manipulations in a shallow, hypereutrophic lake: the relative importance of benthic nutrient recycling and trophic cascade. Hydrobiologia 254:73-80.

Heidinger. R. C. 1983. Life history of gizzard shad and threadfin shad as it relates to the ecology of small lake fisheries. Pages $1-18$ in D. Bonneau and $G$. Radonski, editors. Pros and cons of shad. Iowa Conservation Commission. Des Moines.

Hirst. S. C., and D. R. DeVries. 1994. Assessing the potential for direct feeding interactions among larval black bass and larval shad in two southeastern reservoirs. Transactions of the American Fisheries Society 123:173-181

Holanov. S. H.. and J. C. Tash. 1978. Particulate and filter feeding in threadfin shad. Dorosoma pete- nense. at different light intensities. Journal of Fish Biology 13:619-625.

Hooe. M. L. 1991. Crappie biology and management. North American Journal of Fisheries Management $11: 483-484$

Ingram, W., and C. D. Ziebell. 1983. Diet shifts to benthic feeding by threadfin shad. Transactions of the American Fisheries Society 112:554-556.

Jester. D. B.. and B. L. Jensen. 1972. Life history and ecology of the gizzard shad. Dorosoma cepedianum (Le Sueur) with reference to Elephant Butte Lake. New Mexico Agricultural Experiment Station Research Report 218.

Kutkuhn, J. H. 1958. Utilization of plankton by juvenile gizzard shad in a shallow prairie lake. Transactions of the American Fisheries Society 87:80103.

Maceina, M. J.. P. W. Bettoli, and D. R. DeVries. 1994. Use of a split-plot analysis of variance design for repeated-measures fishery data. Fisheries (Bethesda) 19(3):14-20.

Maceinn, M. J., P. W. Bettoli, W. G. Klussmann, R. K. Betsill, and R. L. Noble. 1991. Effect of aquatic macrophyte removal on recruitment and growth of black crappies and white crappies in Lake Conroe. Texas. North American Joumal of Fisheries Management 11:556-563.

Miller. R. R. 1960. Systematics and biology of the gizzard shad (Dorosoma cepedianum) and related fishes. U.S. Fish and Wildlife Service Fishery Bulletin 60:371-392.

Miranda. L. E., and R. J. Muncy. 1988. Spawning sequence of largemouth bass, bluegill. and gizzard shad. Proceedings of the Annual Conference Southeastern Association of Fish and Wildlife Agencies 4 l (1987): 197-204.

Mitzner. L. 1981. Influence of floodwater storage on abundance of juvenile crappie and subsequent harvest at Lake Rathbun. Iowa. North American Journal of Fisheries Management 1:46-50.

O'Brien, W. J., B. Loveless, and D. Wright. 1984. Feeding ecology of young white crappie in a Kansas reservoir. North American Joumal of Fisheries Management 4:341-349.

Overmann, G. J., R. D. Hoyt, and G. A. Kindschi. 1980. The larval life history of the crappies (Pomoxis) spp. Transactions of the Kentucky Academy of Science 41:105-115.

Pierce, R. J., T. E. Wissing, and B. A. Megrey. 1981. Aspects of the feeding ecology of gizzard shad in Acton Lake, Ohio. Transactions of the American Fisheries Society 110:391-395.

Rosen. R. A. 1981. Length-dry weight relationships of some freshwater zooplankton. Journal of Freshwater Ecology 1:225-229.

Schoener, T. W. 1970. Nonsynchronous spatial overlap of lizards in patchy habitats. Ecology 51:408418.

Siefer, R. E. 1969. Biology of the white crappie in Lewis and Clark Lake. U.S. Bureau of Sport Fisheries and Wildlife Technical Paper 22.

Sweatman, J. J., and C. C. Kohler. 1991. Validation 
of daily otolith increments for young-of-year white crappies. North American Joumal of Fisheries Management 11:499-503.

Swingle, W. E., and E. W. Shell. 1971. Tables for computing relative conditions of some common freshwater fishes. Alabama Agricultural Experiment Station Auburn University Circular 183.

Timmons. T. J.. W. L. Shelton, and W. D. Davies. 1979. Sampling of reservoir fish populations with rotenone in littoral areas. Proceedings of the Annual Conference Southeastern Association of Fish and Wildlife Agencies 32(1978):474-484.

Tin, H. T. 1982a. Family Centrarchidae, sunfishes. Pages 524-580 in N. A. Auer, editor. Identification of larval fishes of the Great Lakes Basin with emphasis on the Lake Michigan drainage. Great Lakes Fishery Commission. Special Publication 82-3, Ann Arbor, Michigan.

Tin, H. T. 1982b. Family Clupedae, herrings. Pages 64-73 in N. A. Auer, editor. Identification of larval fishes of the Great Lakes Basin with emphasis on the Lake Michigan drainage. Great Lakes Fishery
Commission, Special Publication 82-3. Ann Arbor. Michigan.

Van Den Avyle. M. J., and J. R. Wilson. 1980. Food habits and feeding selectivity of larval Dorosoma spp. in Center Hill Reservoir. Pages 146-156 in L. A. Fuiman, editor. Proceeding of the fourth annual larval fish conference. University of Michigan. Ann Arbor.

Wallace, R. K.. Jr. 1981. An assessment of diet-overlap indexes. Transactions of the American Fisheries Society 110:72-76.

Whiteside, B. G. 1962. Biology of the white crappic. Pomoxis annularis, in Lake Texoma, Oklahoma. Master's thesis. Oklahoma State University. Stillwater.

Willis, D. W. 1987. Reproduction and recruitment of gizzard shad in Kansas reservoirs. North American Journal of Fisheries Management 7:71-80.

Received September 22. 1993 Accepted May 3, 1994 